J. Appl. Glycosci., 52, 253-259 (2005)

(C) 2005 The Japanese Society of Applied Glycoscience

\title{
Improvement of Potato Starch by Conjugating with $\varepsilon$-Poly(L-Lysine) through the Maillard Reaction*
}

(Received November 15, 2004 ; Accepted February 9, 2005)

\author{
Wenhong Yang, Noriko Komine, Makoto Hattori, Yasuhiro Ishii and Koji Takahashi** \\ Department of Applied Biological Science, Faculty of Agriculture, Tokyo University of Agriculture and Technology \\ (3-5-8, Saiwai-cho, Fuchu 183-8509, Japan)
}

\begin{abstract}
Slightly acid-treated potato starch (ATS) granules were conjugated with $\varepsilon$-poly(L-lysine) (PL) by using the Maillard reaction. Coomassie Brilliant Blue staining indicated the conjugation of PL to ATS. The PL content of the ATS-PL conjugate was estimated to be in the rage of about $1.7-2.5 \%$. Conjugation with PL increased the gelatinization temperature, and reduced the swelling, solubility, retrogradation, and digestibility with $\alpha$ - or $\beta$-amylase. The ATS-PL conjugate exhibited 1/4-1/2 lower antibacterial activity toward Escherichia coli, Staphylococcus aureus, Saccharomyces cerevisiae, and Candida utilis than free PL did.
\end{abstract}

Key words: starch, functional change, $\varepsilon$-poly(L-lysine), conjugate, antibacterial activity

Starch is widely used in many foods as a good energy source and as a builder and modifier of their physical properties. However, the recent demands for greater functionality and application of foods has demanded a more effective method for achieving greater functional changes to starch such as conjugation with non-starchy components. We have thus already prepared conjugates consisting of a whey protein isolate and carboxymethyl starch granules $^{1)}$ and of amino acids and carboxymethyl starch granules $^{2}$ with an acid-amide bond by using water-soluble carbodiimide in order to improve the gelatinization and retrogradation behavior. Regulating the growth of microorganisms, however, is particularly important for the processing and storage of foods, since starch has not antibacterial activity, and the exposed starchy foods can easily putrefy depending on their environmental conditions. Therefore, many antibacterial agents, in particular, natural additives are often applied to prevent such putrefaction, and $\varepsilon$-poly(L-lysine) (PL) has been cited as one of the best antibacterial agent for food use. ${ }^{3-5)} \mathrm{PL}$ obtained from a culture broth of Streptomyces abulus is a polycationic peptide with an isopeptide linkage connecting with an $\varepsilon$ amino group and $\alpha$-carboxyl group of L-lysine. ${ }^{6-8)}$

We have previously reported that PL could be conjugated with native potato starch (PS), carboxymethyl potato starch (CMS), and corn starch phosphate monoester (PCS) by the Maillard reaction, and that such conjugation led to a marked decrease in solubility, swelling power, the degree of retrogradation, and digestibility with $\alpha$ - or $\beta$ amylase, and to an increase in the thermal stability of

${ }^{*}$ This paper is dedicated to our mentors, the late Professors Dr. Michinori Nakamura, Dr. Susumu Hizukuri and Dr. Toshiaki Komaki, in memory of their numerous pioneering works and leadership in the field of starch and its related science.

** Corresponding author (Tel. +81-42-367-5712, Fax. +81-42360-8830, E-mail: k-taka@cc.tuat.ac.jp).

Abbreviations: PL, $\varepsilon$-poly(L-lysine); CMS, carboxymethyl starch; DSC, differential scanning calorimetry; $T_{\mathrm{o}}$, onset temperature; $T_{\mathrm{p}}$, peak temperature; $T_{\mathrm{c}}$, conclusion temperature. starch, especially in the cases of starch with a partially distorted internal structure such as CMS and PCS. ${ }^{9)}$ These findings suggest the many advantages for using PLconjugated starch instead of PL alone as an additive. However, in the previous study, the conjugation by the Maillard reaction required a relatively long reaction time (3 or 4 weeks), probably due to the small amount of reducing end-groups in PS, PCS, and CMS. This implies that an increase in reducing end-groups could shorten the conjugation reaction. The authors thus considered using slightly acid-treated starch (ATS) granules with a degree of hydrolysis below $1 \%$ as the initial starch material for the Maillard reaction, because ATS with a degree of $1 \%$ hydrolysis has shown a granular structure similar to that of native PS. ${ }^{10)}$

The ATS-PL conjugates used in this study were prepared by using the Maillard reaction to improve the gelatinization and retrogradation behavior, and to endow antimicrobial ability.

\section{MATERIALS AND METHODS}

Materials. Potato starch (PS; Hokuren Research Institute, Sapporo, Japan) was used after being repeatedly washed with distilled water prior to air-drying (water content, $14.7 \%$ ). $\varepsilon$-Poly(L-lysine) (PL; the average degree of polymerization was 30 ) was supplied by Chisso Co. (Yokohama, Japan). The other reagents were reagent grade commercially available.

Preparation of the slightly acid-treated potato starch (ATS). ATS was prepared as previously described. ${ }^{10)}$ In brief, PS (40 g) was immersed in $1600 \mathrm{~mL}$ of $15 \%(\mathrm{w} / \mathrm{w})$ sulfuric acid at $25^{\circ} \mathrm{C}$ for one day while gently stirring two or three times. The degree of hydrolysis was calculated by the equation; $(0.9 \times$ dissolved saccharide $) /($ starch weight $)$, where the dissolved saccharide as glucose was determined by the phenol-sulfuric acid method. ${ }^{11)}$ When the degree of hydrolysis had reached to $0.1,0.2$, or $0.4 \%$, sulfuric acid solution was removed by filtering through a G-4 glass fil- 
ter, and washing thoroughly with distilled water. ATS samples with a $0.1,0.2$, and $0.4 \%$ degree of hydrolysis (ATS1, ATS2, and ATS4, respectively) were obtained by air-drying.

Preparation of ATS-PL. ATS1, ATS2, or ATS4 (1 g) was dispersed in $1 \mathrm{~mL}$ of a solution containing $100 \mathrm{mg}$ of $\mathrm{PL}$ that had been adjusted to $\mathrm{pH} 7.5$ with $0.1 \mathrm{M} \mathrm{HCl}$, and stored overnight at $4{ }^{\circ} \mathrm{C}$. After lyophilizing the dispersion, the dried reaction mixture was incubated for 7 days at 70 ${ }^{\circ} \mathrm{C}$ and a relative humidity of $79 \%$. The reaction product was washed with distilled water by centrifuging 8 times at $5000 \mathrm{rpm}$ for $10 \mathrm{~min}$ to eliminate unreacted PL, and then air-dried to obtain the ATS1-PL, ATS1-PL2, ATS2-PL, or ATS4-PL conjugate. Similarly treated samples without adding PL were prepared as the controls (Cont ATS1, Cont ATS2, and Cont ATS4).

Measurement of whiteness. The whiteness $(W)$ of each ATS-PL was measured by a digital color-difference meter (Toyo Rika Instruments, Tokyo, Japan) to evaluate the progress of the Maillard reaction. $W$ is defined by the following equation, where $X, Y$, and $Z$ are the CIE tristimulus values ${ }^{12)}$ :

$$
\begin{aligned}
W= & 100-\left[(100-L)^{2}+a^{2}+b^{2}\right]^{1 / 2} \\
& L=10 Y^{1 / 2} \\
& a=17.5(1.02 X-Y) / Y^{1 / 2} \\
& b=7.0(Y-0.847 Z) / Y^{1 / 2}
\end{aligned}
$$

Determination of PL. The PL content of each ATSPL was determined according to the method of Nkonge et $a l{ }^{13)}$ A sample was accurately weighed $(100 \mathrm{mg})$ into a micro-Kjeldahl flask containing the catalyst mixture (110 $\mathrm{mg} ; \mathrm{TiO}_{2}: \mathrm{CuSO}_{4}: \mathrm{K}_{2} \mathrm{SO}_{4}=3: 3: 96, \mathrm{w} / \mathrm{w} / \mathrm{w}$ ), before sulfuric acid $(3.0 \mathrm{~mL})$ was added. The digest was heated for 1-2 $\mathrm{h}$ beyond the point when the solution had cleared, before being cooled and filled up to $100 \mathrm{~mL}$ with distilled water. A working buffer ( $\mathrm{pH}$ 13.7) was made up from $0.36 \mathrm{M}$ sodium potassium tartrate containing $0.2 \mathrm{M}$ $\mathrm{Na}_{2} \mathrm{HPO}_{4}$ and $0.2 \mathrm{M} \mathrm{NaOH}$ (solution $\mathrm{A}$ ) and $2.5 \mathrm{M} \mathrm{NaOH}$ (solution B) on a $1: 1$ volume basis. This buffer (1.5 $\mathrm{mL}$ ) was added to $0.5 \mathrm{~mL}$ of the diluted digest containing 2-10 mg of $\mathrm{N}$. After adding $0.4 \mathrm{~mL}$ of a salicylatenitroprusside reagent (a $100 \mathrm{~mL}$ solution containing $20 \mathrm{~g}$ of sodium salicylate and $30 \mathrm{mg}$ of sodium nitroprusside), the solution was thoroughly mixed and kept at $25^{\circ} \mathrm{C}$ for $20 \mathrm{~min}$, before $0.2 \mathrm{~mL}$ of $5 \%$ hypochlorite solution was added. This reaction mixture was held at $25^{\circ} \mathrm{C}$ for $30 \mathrm{~min}$, and the absorbance at $660 \mathrm{~nm}$ was then measured against a nitrogen-free blank. An ammonium sulfate solution was used as the nitrogen standard.

Microscopic observation. A starch sample $(10 \mathrm{mg})$ was heated in $1 \mathrm{~mL}$ of distilled water at $70^{\circ} \mathrm{C}$ for $10 \mathrm{~min}$, before being cooled to room temperature. After mixing with $1 \mathrm{~mL}$ of a Coomassie Brilliant Blue solution (CBB, $10 \mathrm{mg} / \mathrm{mL}$ ) for $15 \mathrm{~min}$, the sample was washed with distilled water by centrifuging at $3000 \mathrm{rpm}$ for $15 \mathrm{~min}$ three times, and then observed using a polarizing microscope (model PM-10AD sp, Olympus, Tokyo, Japan).

Solubility measurement. The solubility of each ATSPL heated at 60 or $95^{\circ} \mathrm{C}$ was evaluated by determining the saccharide concentration of the centrifuged supernatant (at $18,000 \mathrm{rpm}$ for $10 \mathrm{~min}$ at $20^{\circ} \mathrm{C}$ ) by the phenol-sulfuric acid method $^{11)}$ as previously described. ${ }^{1,2)}$
Differential scanning calorimetry (DSC). Starch gelatinization was studied by a SSC-5020 DSC 100 apparatus (SSI Technologies, Chiba, Japan) as previously described, ${ }^{14)}$ and the degree of retrogradation $\left(4^{\circ} \mathrm{C}\right.$ for 7 days) of the starch sample was evaluated as previously described. ${ }^{14,15)}$

Digestibility of the starch moiety with $\alpha$ - and $\beta$ amylases. The digestibility with $\alpha$-amylase (EC 3.2.1.1; Sigma, St. Louis, USA) was evaluated according to the method described previously. ${ }^{1,2}$ In brief, a sample (2 mg) was dispersed in $1 \mathrm{~mL}$ of a $0.02 \mathrm{M}$ sodium citrate buffer (pH 6.5) containing $0.1 \mathrm{M}$ sodium chloride, and then heated at $100^{\circ} \mathrm{C}$ for $10 \mathrm{~min}$ without stirring. After cooling to room temperature, 1 unit of $\alpha$-amylase in $1 \mathrm{~mL}$ of the citrate buffer was added, and then the reaction mixture was incubated at $30^{\circ} \mathrm{C}$ for $2 \mathrm{~h}$. The digestibility was evaluated by determining the saccharide concentration of the filtrate passing through a membrane filter with a 0.45 $\mu \mathrm{m}$-pore size (cellulose nitrate; Advantec, Tokyo, Japan) by the phenol-sulfuric acid method. ${ }^{11)}$

The digestibility with $\beta$-amylase (EC 3.2.1.2, type I-B from sweet potato; Sigma, St. Louis, USA) was measured as previously described. ${ }^{1,2)}$ A sample $(2 \mathrm{mg})$ was dispersed in a solution of $1.9 \mathrm{~mL}$ of distilled water and $0.1 \mathrm{~mL}$ of a $1 \mathrm{M}$ acetate buffer ( $\mathrm{pH} 6.0$ ), and heated at $100^{\circ} \mathrm{C}$ for 10 min without stirring. After cooling to room temperature, 100 units of $\beta$-amylase in $0.1 \mathrm{~mL}$ of the acetate buffer was added, and then the reaction mixture was incubated at $30^{\circ} \mathrm{C}$ for $2 \mathrm{~h}$. The digestibility was evaluated by determining the saccharide concentration of the filtrate as described just above.

Measurement of the antibacterial activity. Escherichia coli (IFO 3301) for the gram-positive bacterium, Staphylococcus aureus (IFO 3183) for the gramnegative bacterium, Saccharomyces cerevisiae (IFO 0555), and Candida utilis (IFO 0396) for a yeast were obtained as test organisms from the Institute of Fermentation (Osaka, Japan). The former two strains (E. coli and $S$. aureus) and the latter two strains (C. utilis and S. cerevisiae) were respectively inoculated on slants of a $\mathrm{BHY}$ medium (3.7 $\mathrm{g}$ of a brain heart infusion medium, $9 \mathrm{~g}$ of polypeptone, $5 \mathrm{~g}$ of yeast extract, $2.8 \mathrm{~g}$ of glucose, $15 \mathrm{~g}$ of glycerol, $15 \mathrm{~g}$ of agar, and water to $1 \mathrm{~L}$ ) and YM medium (5 $\mathrm{g}$ of polypeptone, $3 \mathrm{~g}$ of malt extract, $3 \mathrm{~g}$ of yeast extract, $10 \mathrm{~g}$ of glucose, $15 \mathrm{~g}$ of agar, and water to $1 \mathrm{~L}$ ), and cultured at $30^{\circ} \mathrm{C}$ for 2 days. After the cells had been subcultured twice on slant cultures, the strains were preserved at $5^{\circ} \mathrm{C}$ before use in an antibacterial assay.

The minimum inhibitory concentration of PL to each test organisms was then determined as follows. Cells were precultured to the logarithmic or stationary growth phase in a NB-5\%G liquid medium (10 $\mathrm{g}$ of polypeptone, $5 \mathrm{~g}$ of meat extract, $5 \mathrm{~g}$ of $\mathrm{NaCl}, 50 \mathrm{~g}$ of glucose, and water to 1 L) at $30^{\circ} \mathrm{C}$ for $1-2$ days. The precultured suspension (100 $\mu \mathrm{L}$ ) was transferred to $4 \mathrm{~mL}$ of the fresh $\mathrm{NB}-5 \% \mathrm{G}$ liquid medium, and a PL solution adjusted to $\mathrm{pH} 7.0$ with $0.1 \mathrm{M}$ $\mathrm{HCl}$ was added to give concentrations of $0-200 \mu \mathrm{g} / \mathrm{mL}$. After incubating at $30^{\circ} \mathrm{C}$ for 2 days, the minimum inhibitory concentrations of PL to each organism was determined as the PL concentration resulting in no increase in the absorbance at $600 \mathrm{~nm}$ of the culture suspension. 
Table 1. Conditions for determining the antibacterial activity of ATS-PLs.

\begin{tabular}{lccc}
\hline \multirow{2}{*}{ Test organism } & \multicolumn{2}{c}{ Concentration } & \\
\cline { 2 - 3 } & $\begin{array}{c}\text { MIC of PL } \\
(\mu \mathrm{g} / \mathrm{mL})\end{array}$ & $\begin{array}{c}\text { Organism } \\
(\text { cells } / \mathrm{mL})\end{array}$ & $\begin{array}{c}\text { Culture } \\
\text { temp. }\left({ }^{\circ} \mathrm{C}\right)\end{array}$ \\
\hline Escherichia coli IFO 3301 & 40 & $5 \times 10^{2}$ & 25 \\
Staphylococcus aureus IFO 3183 & 80 & $5 \times 10^{1}$ & 30 \\
Saccharomyces cerevisiae IFO 0555 & 60 & $5 \times 10^{2}$ & 25 \\
Candida utilis IFO 0396 & 20 & $5 \times 10^{4}$ & 25 \\
\hline
\end{tabular}

MIC, minimum inhibitory concentration.

The number of cells for the assay was determined after preculturing at $30^{\circ} \mathrm{C}$ for 2 days in the $\mathrm{NB}-5 \% \mathrm{G}$ liquid medium. The cell suspension was diluted with the fresh medium to $10^{2}-10^{8}$ viable cell counts $/ \mathrm{mL}$ with the fresh medium as determined by referring to a curve of the absorbance at $600 \mathrm{~nm}$ versus the cell number as drawn previously, and then $1 \mathrm{~mL}$ of the diluted suspension was added to $19 \mathrm{~mL}$ of the fresh medium containing the minimum inhibitory concentrations of PL to each organism. The most suitable cell number for assay was determined as the cell number without any increase in the absorbance at $600 \mathrm{~nm}$ of the cultured suspension after $24 \mathrm{~h}$. The minimum inhibitory concentration of PL, the cell number for the assay, and the culture temperature are listed in Table 1.

The antibacterial activity of ATS1-PL was evaluated by the absorbance of the liquid culture broth and the viable cells as follows. Each test organism was precultured for 2 days at $30^{\circ} \mathrm{C}$, and the test organism suspension was diluted to around the concentration shown in Table 1. ATS1PL containing 1, 2, 3, or 4-fold PL of the minimum inhibitory concentration of free PL itself was weighed into a $50 \mathrm{~mL}$ of Erlenmeyer flask, and $3 \mathrm{~mL}$ of distilled water was added. After autoclaving at $121^{\circ} \mathrm{C}$ for $20 \mathrm{~min}, 18 \mathrm{~mL}$ of the NB-5\%G liquid medium, and $1 \mathrm{~mL}$ of the suspension of the test organism were added. Each inoculated suspension was cultured for five days at $25^{\circ} \mathrm{C}$ for E. coli, S. cerevicsae, and C. utilis, or at $30^{\circ} \mathrm{C}$ for S. aureus. The antibacterial activity was judged according to the growth of the test organism by measuring every day the absorbance of $2 \mathrm{~mL}$ of the cultured suspension at $600 \mathrm{~nm}$. To determine the viable cells count, $1 \mathrm{~mL}$ of the same culture suspension was taken into a test tube, and diluted to a concentration of around $10^{1}-10^{3}$ cells $/ \mathrm{mL}$ with $0.9 \%$ $\mathrm{NaCl}$. Then a $1 \mathrm{~mL}$ volume of this diluted suspension was spread on an $\mathrm{NB}-5 \% \mathrm{G}$ medium plate, which was incubated at $30^{\circ} \mathrm{C}$ for $1-10$ days. The colonies formed were considered as the number of viable cells. The ATS1, 2ATS1, 3ATS1, and 4ATS1 samples similarly treated but without adding PL and the ATS1+PL mixture of starch and PL with the same content as each conjugate were used as the controls.

\section{RESULTS AND DISCUSSION}

\section{Conjugation of starch with PL.}

The whiteness of each reaction mixture of ATSs and PL decreased with an increase in the degree of hydrolysis of ATS after incubation at $70^{\circ} \mathrm{C}$ for 1 week (Fig. 1), indicative of a considerably shortened reaction period as

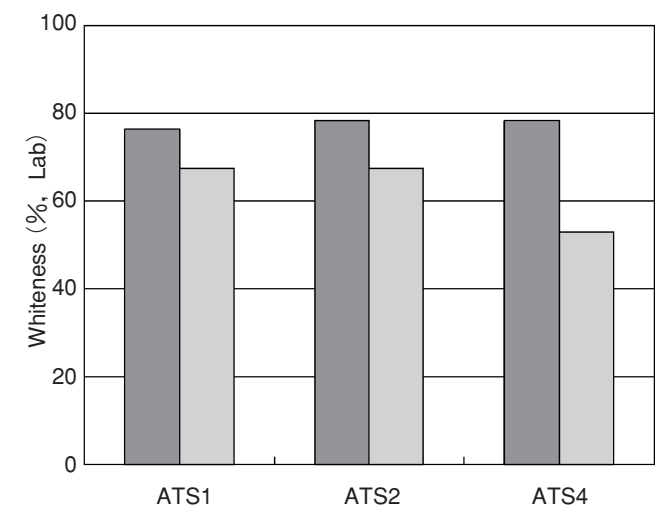

Fig. 1. Whiteness of the ATS-PL conjugates.

Cont, control acid-treated potato starch (ATS); ATS1, ATS with $0.1 \%$ degree of hydrolysis; ATS2, ATS with $0.2 \%$ degree of hydrolysis; ATS4, ATS with $0.4 \%$ degree of hydrolysis. $\square$, Cont ATS; $\square$, ATS-PL conjugate.
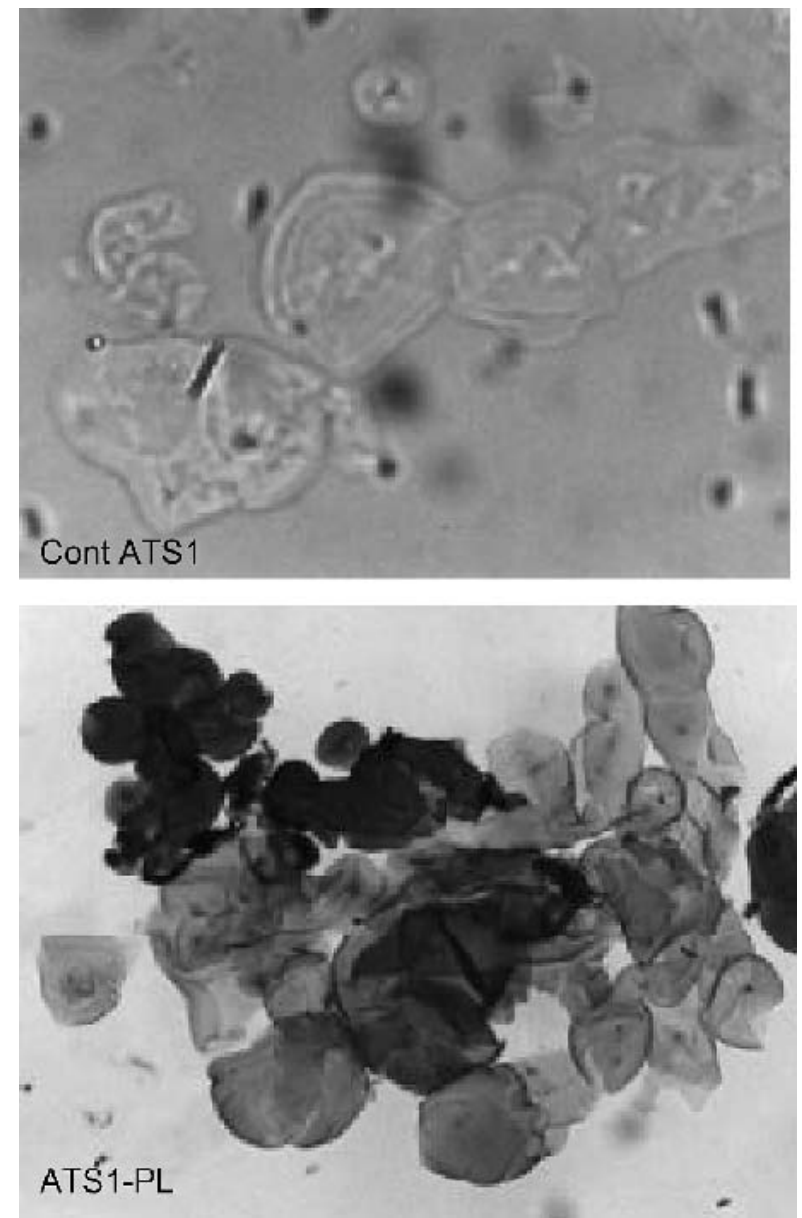

Fig. 2. Polarized micrographs of ATS1-PL and ATS1 after heating at $70^{\circ} \mathrm{C}$ and staining with $\mathrm{CBB}$.

Direct magnification, $\times 100$. 
compared with that (3 or 4 weeks) for native potato starch (PS), carboxymethyl potato starch (CMS), or corn starch phosphate mono ester (PCS) reported in the previous paper.' ${ }^{9)}$ This development of browning is thus considered to indicate the conjugation of ATS with PL by the Maillard reaction. The PL contents of ATS1-PL, ATS2-PL, and ATS4-PL were respectively determined to be $2.5,1.7$, and $2.1 \%$, being independent of the degree of hydrolysis of ATS. All ATS-PLs showed the clear polarizing patterns similar to that of native potato starch (data not shown) and indicative of the maintenance of a micelle structure similar to that of native starch. The gelatinized samples of ATS-PLs could be strongly stained with CBB, whereas Cont ATS could not be stained (Fig. 2). It is considered from these results that PL could be conjugated with the starch granules by the Maillard reaction.

\section{Reduced swelling and solubility.}

The Cont ATS samples swelled greatly at $50^{\circ} \mathrm{C}$, and dispersed almost completely at $70^{\circ} \mathrm{C}$ for $10 \mathrm{~min}$, whereas each ATS-PL had markedly less swelling (Fig. 2). The solubility of each ATS-PL at both $60^{\circ} \mathrm{C}$ and $95^{\circ} \mathrm{C}$ was lower than that of each Cont ATS sample (Fig. 3). In particular, ATS1-PL with the highest PL content exhibited low solubility. It is thus considered that conjugation with

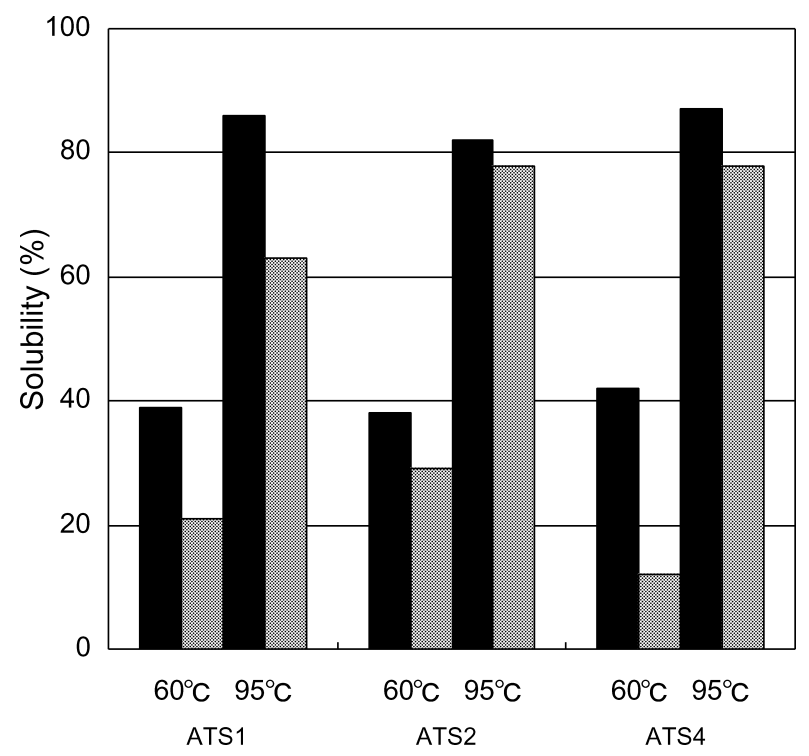

Fig. 3. Solubility of ATS-PLs.

ATS-PLs were dissolved in distilled water at $60^{\circ} \mathrm{C}$ or $95^{\circ} \mathrm{C}$ for 1 $\mathrm{h}$, and the solubility was evaluated by determining the saccharide concentration of the centrifuged supernatant (at 18,000 rpm for 10 min) according to the phenol-sulfuric acid method. ${ }^{11)}$, Cont ATS; $\square$, ATS-PL conjugate.
PL could decrease the swelling and solubility of the starch, probably due to restriction of the mobility and the migration of the starch chains from the inside of the granules. Another possible reason is that a PL containing 31 amino groups could be conjugated with more than one starch chain being cross-linked. It is thus considered that conjugation with PL can be expected to improve such physical properties as the viscosity or stickiness of starchy foods as has previously been shown in the case of native PS, CMS, and PCS."

\section{Regulation of the thermal behavior.}

The thermal behavior of ATS-PLs was investigated by DSC in respect to the changes in gelatinization and retrogradation. The onset temperature $\left(T_{0}\right)$ of the Cont ATS sample showed lower gelatinizaton temperatures and enthalpies than the values of native PS $\left(58.9^{\circ} \mathrm{C}\right.$ and 19.5 $\mathrm{mJ} / \mathrm{mg}$, respectively) due to cracking damage at the hilum by air-drying, ${ }^{10)}$ while $T_{\mathrm{o}}$ of the Cont ATS sample increased with increasing degrees of hydrolysis, in agreement with the previous finding ${ }^{10)}$ (Table 2). ATS-PLs gelatinized at about $2-7^{\circ} \mathrm{C}$ higher $T_{\mathrm{o}}$ than did the Cont ATS samples, and the thermal transition was sharp (Table 2). This indicates that conjugation with PL could stabilize the internal structure of the ATS granule, probably due to restricting the free motion of the starch chains through crosslinking between amino groups of PL and the reducing ends of the multiple starch chains. However, there was no distinct change in gelatinization enthalpy between the Cont ATS samples and their conjugates.

The retrograded ATS-PLs were analyzed again by DSC. The ratio of the second gelatinization enthalpy to that from the first analysis can be regarded as the degree of retrogradation. ${ }^{14,15)}$ The Cont ATS samples showed a markedly higher degree of retrogradation than that for the value $(57.7 \%)$ of native PS, ${ }^{9)}$ indicating the easy retrogradation of ATS, whereas ATS-PLs showed a very low degree of retrogradation, as is generally the case. ${ }^{10)}$ It is likely that these conjugates resisted retrogaradation due to the restriction on rearrangement of the starch chains from reduced free motion and steric hindrance of the conjugated PL.

\section{Digestibility with $\alpha$ - or $\beta$-amylase.}

The Cont ATS samples were mostly digested with $\alpha$ and $\beta$-amylases within $2 \mathrm{~h}$ (Fig. 4). The Cont ATS samples could be readily dissolved by pre-heating at $100^{\circ} \mathrm{C}$ for $10 \mathrm{~min}$ as shown Fig. 3, so it is considered that they were readily digested with amylases. However, the di-

Table 2. Gelatinization temperature, enthalpy and degree of retrogradation of ATS-PLs compared with those of the control ATS samples.

\begin{tabular}{|c|c|c|c|c|c|}
\hline \multirow{2}{*}{ Conjugate } & \multicolumn{3}{|c|}{ Gelatinization temp. $\left({ }^{\circ} \mathrm{C}\right)$} & \multirow{2}{*}{$\begin{array}{l}\text { Enthalpy } \\
(\mathrm{mJ} / \mathrm{mg})\end{array}$} & \multirow{2}{*}{$\begin{array}{l}\text { Degree of } \\
\text { retrogradation } \\
(\%)\end{array}$} \\
\hline & $T_{\mathrm{o}}$ & $T_{\mathrm{p}}$ & $T_{\mathrm{c}}$ & & \\
\hline Native PS & 55.4 & 59.6 & 66.0 & 14.7 & 34.7 \\
\hline Cont ATS1 & 45.6 & 55.7 & 67.8 & 6.8 & 116.2 \\
\hline ATS1-PL & 52.9 & 58.4 & 66.1 & 9.3 & 61.3 \\
\hline Cont ATS2 & 46.8 & 58.7 & 75.0 & 5.7 & 163.3 \\
\hline ATS2-PL & 52.8 & 58.2 & 66.7 & 3.5 & 42.9 \\
\hline Cont ATS4 & 50.9 & 57.9 & 70.0 & 10.2 & 73.3 \\
\hline ATS4-PL & 52.5 & 59.0 & 68.2 & 9.2 & 33.7 \\
\hline
\end{tabular}



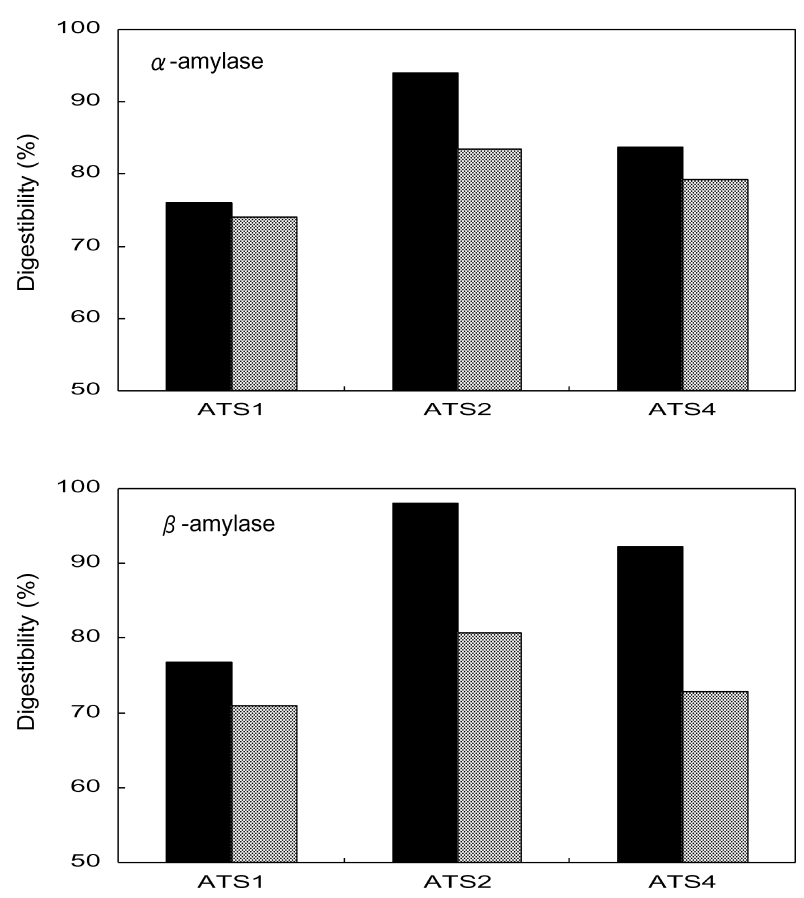

Fig. 4. Digestibility of ATS-PLs with $\alpha$-and $\beta$-amylases.

Each sample was heated at $100^{\circ} \mathrm{C}$ for $10 \mathrm{~min}$. After cooling to room temperature, $\alpha$-amylase or $\beta$-amylase was added, and the reaction mixture was incubated at $30^{\circ} \mathrm{C}$ for $2 \mathrm{~h}$. The digestibility was evaluated by determining the saccharide concentration of the filtrate according to the phenol-sulfuric acid method. ${ }^{11)} \square$, Cont ATS; $\square$, ATS-PL conjugate.

gestibility of ATS-PLs with $\alpha$-amylase decreased to 8997\% of those of the Cont ATS samples, corresponding to the reduced solubility. This reduced digestibility and solubility suggest that the internal structure of ATS-PLs was more stable than that of the Cont ATS samples. The reduction in digestibility shown by the assay with $\beta$ amylase was greater than that with $\alpha$-amylase. Since $\beta$ amylase is an exo type, the PL chains conjugated at the reducing ends of the starch chains may have inhibited the digestion with $\beta$-amylase from the non-reducing ends of neighboring starch chains due to steric hindrance. These results suggest that resistance to digestion with $\alpha$ - and $\beta$ amylase could be brought to pre-gelatinized starch by conjugating with PL.

\section{Antibacterial ability of the ATS-PL conjugate.}

The antibacterial activity of ATS1-PL against four test organisms (E. coli, S. aureus, S. cerevisiae, and C. utilis) was evaluated by the absorbance of the liquid medium. Antibacterial activity of ATS1 was not apparent in the medium containing ATS1 without adding PL, since the organisms multiplied within $24 \mathrm{~h}$ from the increased absorbance (Fig. 5). In contrast, the development of each test organism in the medium with PL added at the minimum inhibitory concentration (PL+ATS1) was completely impaired, confirming the antibacterial activity of PL in the medium containing starch. However, ATS1-PL containing the same PL concentration as the minimum inhibitory concentration for free PL could not completely inhibit multiplication of the organisms during $48 \mathrm{~h}$ (data
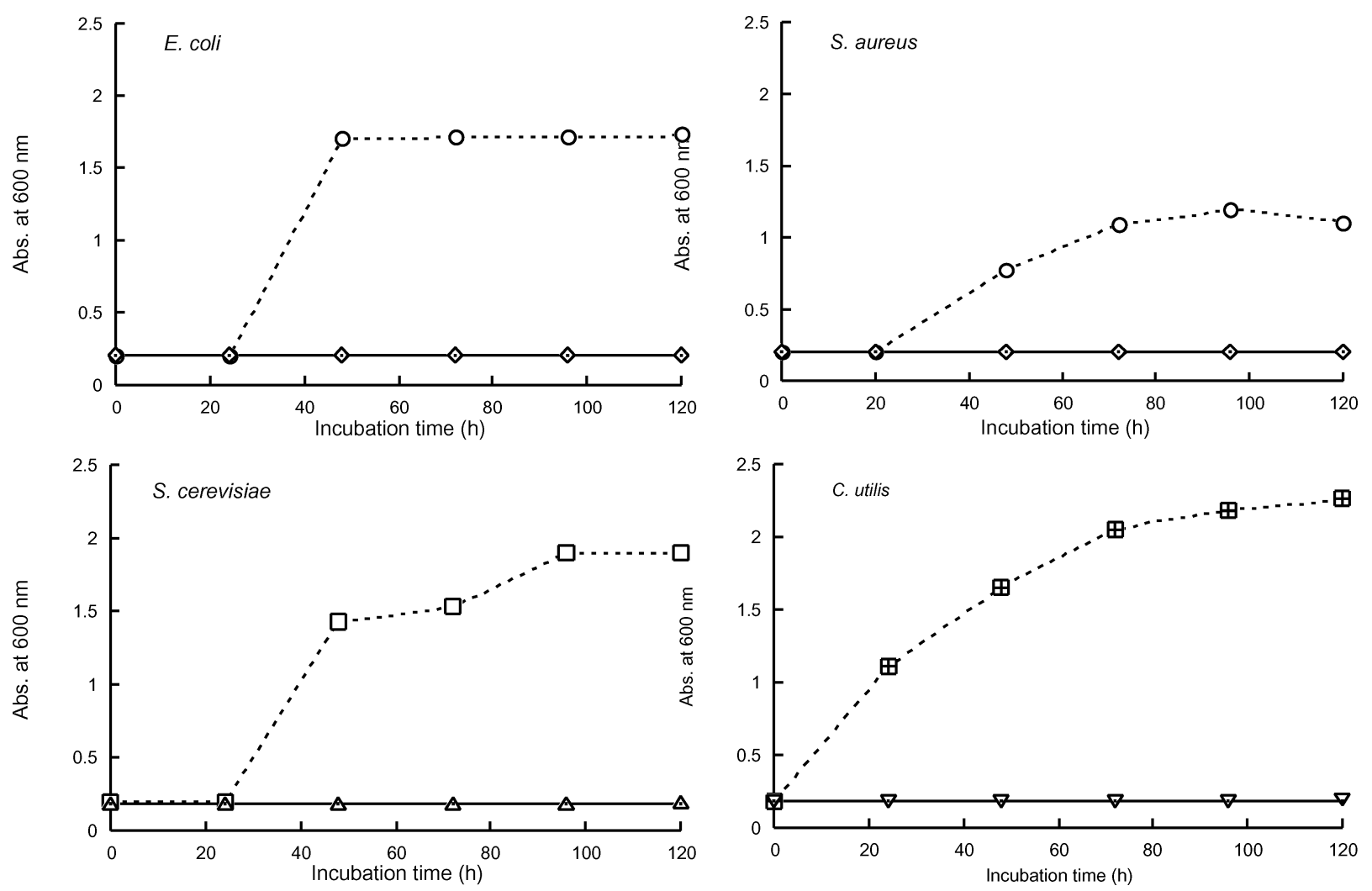

Fig. 5. Antibacterial activity of ATS1-PL evaluated by the absorbance of the liquid medium.

ATS1-PL containing from 2- to 4-fold PL of the minimum inhibitory concentration for free PL itself was tested to evaluate the antibacterial activity. ATS with the same content as ATS1-PL was similarly tested. $\diamond$, the conjugate containing 4-fold the free PL conc.; $\bigcirc$, ATS1 with the same content as the 4-fold conjugate conc.; $\triangle$, the conjugate containing 3-fold the free PL conc.; $\square$, ATS1 with the same content as the 3-fold conjugate conc.; $\nabla$, the conjugate containing 2-fold the free PL conc.; $\boxplus$, ATS1 with the same content as the 2-fold conjugate conc.; - , mixture of free PL (MIC) and AST1. 

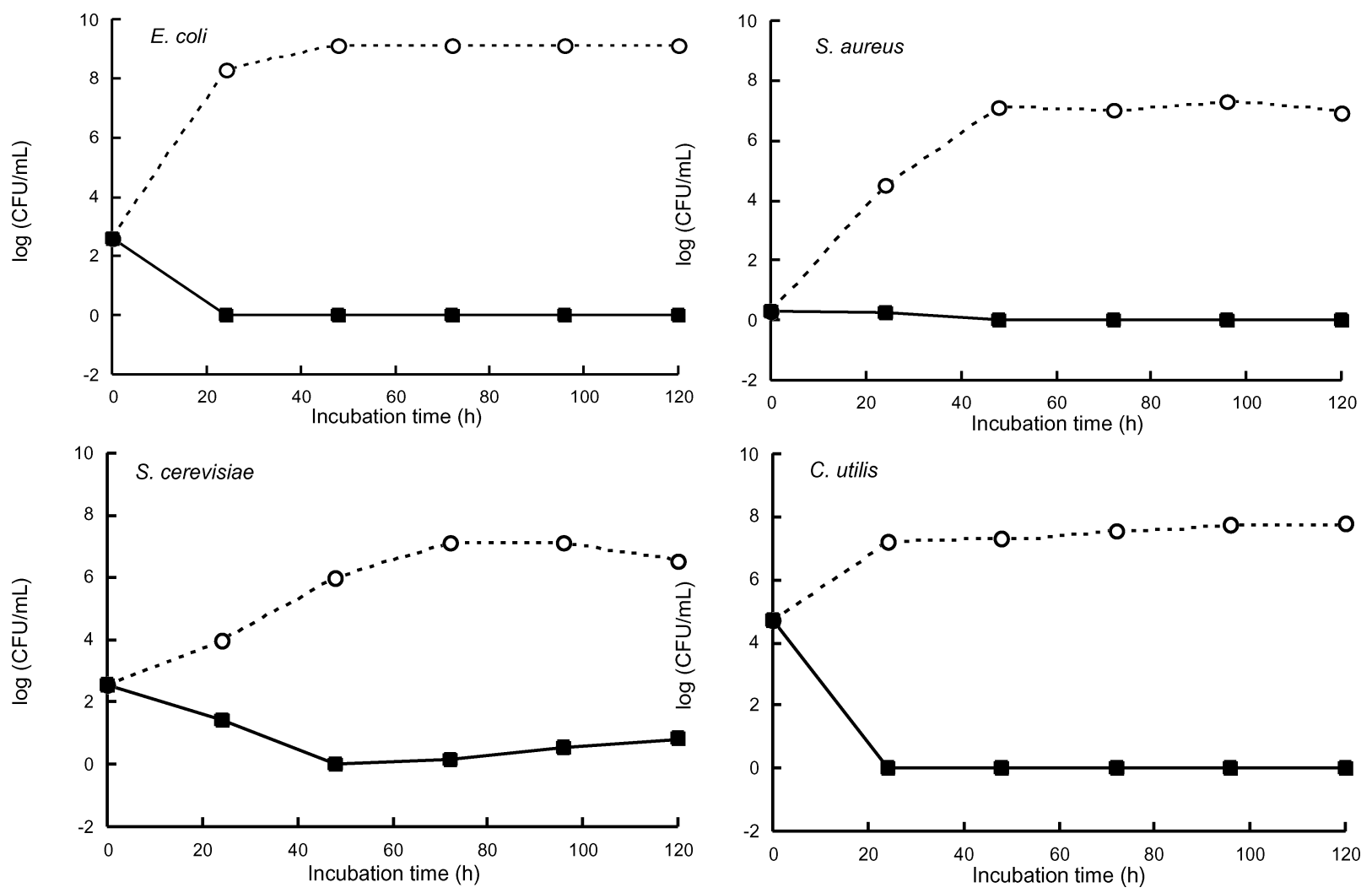

Fig. 6. Antibacterial activity of ATS1-PL evaluated by viable cell count.

ATS1-PL containing 4-fold PL of the minimum inhibitory concentration for free PL itself was tested to evaluate the antibacterial activity. ATS with the same content as ATS1-PL was similarly tested. $\mathbf{\square}$, ATS1-PL; $\bigcirc$, ATS1.

not shown). ATS1-PL containing 2-, 3-, or 4-fold PL (2ATS1-PL, 3ATS1-PL, and 4ATS1-PL) at the minimum inhibitory concentration was thus added to the medium. This inhibited the increase in absorbance of each medium, and definitive antibacterial activity against the four test organisms was apparent. Therefore, ATS1-PL had antibacterial activity against a wide range of microorganisms leading to gram-positive bacteria, gram-negative bacteria, and yeasts. However, the antibacterial activity of ATS1PL was $1 / 2-1 / 4$ that of free PL. Since the antibacterial activity of PL is dependent on polycations, ${ }^{16)}$ this reduced antibacterial activity is considered to have been caused by the loss of charge by conjugating with ATS. Another possible reason could have been that the low mobility of the conjugated PL in starch granules resulted in less contact of the cell wall in the medium than that of free PL. In the case of $C$. utilis, the addition of ATS1-PL containing 2fold PL of the minimum inhibitory concentration exhibited sufficient antibacterial activity in comparison with the other three organisms.

The antibacterial activity of ATS1-PL was also evaluated by the viable cell count. When ATS1-PL containing 1- or 2-fold PL of the minimum inhibitory concentration for free PL was added to the media, multiplication of the organisms could not be completely inhibited (data not shown). Thus, ATS1-PL containing 4-fold the minimum inhibitory concentration of PL added to the media exhibited viable cell counts of the test organisms, except for $S$. cerevisiae, of almost 0 within $24 \mathrm{~h}$ (Fig. 6). In the case of $S$. cerevisiae, the viable cell count became 0 within $48 \mathrm{~h}$, but there was a slight multiplication of the organism after 72 h. These results demonstrate that conjugation with PL and starch through the Maillard reaction could endow the starch with antibacterial activity.

\section{CONCLUSION}

Slightly acid-treated potato starch granules were conjugated with $\varepsilon$-poly(L-lysine) (PL) by the Maillard reaction, having $0.2-8.1 \%$ of the PL content. The resulting conjugates exhibited an increased gelatinization temperature, reduced swelling, solubility, retrogradation, and digestibility with $\alpha$ - and $\beta$-amylase, and $1 / 4-1 / 2$ less antibacterial activity than free PL against Escherichia coli, Staphylococcus aureus, Saccharomyces cerevisiae, and Candida utilis. It is therefore considered that conjugation with PL would be valuable for providing a new composite starch material with improved swelling, gelatinization and retrogradation behavior, reduced digestibility, and enhanced antibacterial ability.

We are grateful to Mr. T. Michishiita of Hokuren Research Institute and Dr. J. Hiraki of Chisso Yokohama Research Center for respectively donating the potato starch and $\varepsilon$-poly(L-lysine).

\section{REFERENCES}

1) M. Hattori, W.-H. Yang and K. Takahashi: Functional changes of carboxymethyl potato starch by conjugation with whey proteins. J. Agric. Food Chem., 43, $2007-2011$ (1995).

2 ) W.-H. Yang, M. Hattori and K. Takahashi: Functional changes of carboxymethyl potato starch by conjugation with amino acids. Biosci. Biotechnol. Biochem., 59, 2203-2206 (1995).

3 ) S. Shima, Y. Fukuhara and H. Sakai: Inactivation of bacteriophages by $\varepsilon$-poly-L-lysine produced by Streptomyces. Agric. 
Biol. Chem., 46, 1917-1919 (1982).

4 ) S. Shima, H. Matsuoka, T. Iwamoto and H. Sakai: Antimicrobial action of $\varepsilon$-poly-L-lysine. J. Antibiotics, 37, 1449-1455 (1984).

5 ) N. Delihas, L.W. Riley, W. Loo, J. Berkowitz and N. Poltoratskaia: High sensitivity of mycobacterium species to the bactericidal activity by polylysine. FEMS Microbiol. Lett., 132, 233-237 (1995).

6 ) S. Shima and H. Sakai: Polylysine produced by Streptomyces. Agric. Biol. Chem., 41, 1807-1809 (1977).

7 ) S. Shima and H. Sakai: Poly-L-lysine produced by Streptomyces. Part II. Taxonomy and fermentation studies. Agric. Biol. Chem., 45, 2497-2502 (1981).

8 S. Shima and H. Sakai: Poly-L-lysine produced by Streptomyces. Part III. Chemical studies. Agric. Biol. Chem., 45, 25032508 (1981).

9 ) W.-H. Yang, M. Hattori, T. Kawaguchi and K. Takahashi: Properties of starches conjugated with lysine and poly(lysine) by the Maillard reaction. J. Agric. Food Chem., 46, 442-445 (1998).

10) K. Takahashi, M. Hattori and K. Wada: Reversible molecular rearrangement of slightly acid-treated starches. J. Food Sci., 59, 637-640 (1994).

11) M. Dubois, K.A. Gilles, J.K. Hamilton, P.A. Rebers and F. Smith: Colorimetric method for determination of sugars and related substances. Anal. Chem., 28, 350-356 (1956).

12) Method 6131: Yellowness index. Fed. Test Method Std. 1986, No. $141 \mathrm{c}$.

13) C. Nkonge and G.M. Ballance: A sensitive colorimetric procedure for nitrogen determination in Micro-Kjeldahl digests. $J$. Agric. Food Chem., 30, 416-420 (1982).

14) K. Takahashi, K. Shirai and K. Wada: Melting behavior of gels prepared from isolated subunits of collagen. J. Food Sci., 53, 1920-1921 (1988).

15) F. Nakazawa, S. Noguchi, J. Takahashi and M. Takada: Retrogradation of gelatinized potato starch studied by differential scanning calorimetry. Agric. Biol. Chem., 49, 953-957 (1985).

16) A. Kanazawa, T. Ikeda and T. Endo: Polycationic biocides. $J$. Antibact. Antifung. Agents, 23, 87-97 (1995) (in Japanese).

\section{メイラード反応を介した $\varepsilon$-ポリリシン結合による 馬鈴薯澱粉の改質}

楊 文紅, 小峰法子, 服部 誠, 石井泰博 高橋幸資

\section{東京農工大学農学部（183-8509 府中市幸町 3-5-8）} 軽微な硫酸処理馬鈴著澱粉粒をメイラード反応により と-ポリリシンと結合した. Coomassie Brilliant Blueに よって硫酸処理澱粉とを-ポリリシンの結合を確認した. 複合体の $\varepsilon$-ポリリシン含量は $1.7-2.5 \%$ であった。 $\varepsilon$-ポ リリシンとの複合化は, 糊化温度の上昇, 膨潤, 溶解性, 老化抢よび $\alpha-, \beta$-アミラーゼ被消化性の低下をもたら した. Escherichia coli, Staphyrococcus aureus, Saccharomyces cereviciae 㧍よび Candida utilis に対して, 複合体は, 遊離 $\varepsilon$-ポリリシンより $1 / 4-1 / 2$ 低い抗菌活性を示した。 